\title{
Generation of differentially regulated genes in Mycobacterium tuberculosis isolates from cerebrospinal fluid and respiratory secretions using suppression subtractive hybridization
}

\author{
SH Saw ${ }^{1,2^{*}}$, VC Yong ${ }^{3}$, YF Ngeow ${ }^{1}$ \\ From 2nd International Science Symposium on HIV and Infectious Diseases (HIV SCIENCE 2014) \\ Chennai, India. 30 January - 1 February 2014
}

\section{Background}

Suppression Subtractive Hybridization (SSH) is an established method for separating DNA molecules that distinguish two closely related DNA samples, which has become a powerful method for generating subtracted cDNA libraries. In this study, we postulated that SSH could be used to identify significant genetic differences between Mycobacterium tuberculosis causing meningitis and M. tuberculosis causing pulmonary tuberculosis.

\section{Hypothesis}

The unique DNA patterns present only in cerebrospinal fluid (CSF) TB isolates might be markers for neurotropism and neurovirulence in some strains of $M$. tuberculosis.

\section{Methods}

Bacterial DNAs were isolated and SSH was performed using PCR-Select Bacterial Genome Subtraction Kit (Clontech). Twenty subtracted DNAs were generated from 3 CSF isolates and 3 respiratory isolates. Molecular cloning was done on the subtracted DNAs and the positive isolates were extracted, purified and sequenced for analysis.

\section{Results}

So far, 9 of the subtracted DNAs have been successfully cloned into pGEM-T vector, resulting in 21 positive clones. Two preliminary BLASTP results revealed several mycobacterial PE/PPE proteins which play a role in the evasion of host immune responses, possibly via antigenic

\footnotetext{
* Correspondence: sawsh@utar.edu.my

'Department of Medical Microbiology, Faculty of Medicine, University of

Malaya, Kuala Lumpur-50603, Malaysia

Full list of author information is available at the end of the article
}

variation, together with conserved hypothetical proteins with unknown function.

\section{Conclusion}

Further studies are needed to determine the role of these subtracted DNAs.

\section{Authors' details}

'Department of Medical Microbiology, Faculty of Medicine, University of Malaya, Kuala Lumpur-50603, Malaysia. ${ }^{2}$ Department of Biomedical Science, Faculty of Science, Universiti Tunku Abdul Rahman, Kampar Pera-31900, Malaysia. ${ }^{3}$ School of Biosciences, Taylor's University Lakeside Campus, Subang Jaya, Selangor Darul Ehsan-47500, Malaysia.

Published: 27 May 2014

\section{doi:10.1186/1471-2334-14-S3-016}

Cite this article as: Saw et al:: Generation of differentially regulated genes in Mycobacterium tuberculosis isolates from cerebrospinal fluid and respiratory secretions using suppression subtractive hybridization. BMC Infectious Diseases 2014 14(Suppl 3):O16.

Submit your next manuscript to BioMed Central and take full advantage of:

- Convenient online submission

- Thorough peer review

- No space constraints or color figure charges

- Immediate publication on acceptance

- Inclusion in PubMed, CAS, Scopus and Google Scholar

- Research which is freely available for redistribution 